\title{
IMPLEMENTASI EXCELLENT SERVICE DI MADRASAH ALIYAH NEGERI 1 BANDAR LAMPUNG
}

\author{
Jamal Fakhri \\ jamalfakhri@radenintan.ac.id \\ Universitas Islam Negeri Raden Intan Lampung
}

\begin{abstract}
This study aims to analyze the ability of MAN 1 in implementing an excellent service in the field of education. Data is collected through (i) interviews, using interview guides in the form of detailed data on questions to be given to the principal, head of administration, administrative staff, curriculum waka, student affairs, infrastructure, community relations, treasurer committee, treasurer expenses, students and librarians. (ii) observation, namely non passive participants. Researchers did not interfere with the school administration's activities as a whole. (iii) Documentary studies, namely methods for finding data through things such as notes, interviews, photographs of administrative activities at school. The results of the documentation study are used as evidence that researchers have carried out research in the field of observation and documentation study. While the results of this study are: The program for improving the quality of education in MAN 1 in general is in accordance with the eight National Education Standards (SNP). Educational quality improvement programs have been formulated even though they are still global in nature.
\end{abstract}

Keywords: Excellent service, Implementation, and Madrasas

\begin{abstract}
Abstrak
Penelitian ini bertujuan untuk menganilis kemampuan MAN 1 dalam menerapkan excellent service dalam bidang pendidikan. Data dikumpulkan melalui (i) wawancara, menggunakan panduan wawancara (interview guide) berupa rincian data pertanyaan yang akan diberikan kepada kepala sekolah, kepala tata usaha, tenaga administrasi, waka kurikulum, waka kesiswaan, waka sarana prasarana, waka hubungan masyarakat, bendahara komite, bendahara pengeluaran, peserta didik dan pustakawan. (ii) observasi, yaitu non partisipan pasif. Peneliti tidak ikut campurdengan kegiatan administrasi sekolah secara keseluruhan. (iii) Studi dokumentasi yaitu metode untuk mencari data melalui hal-hal seperti catatan, hasil wawancara, foto kegiatan administrasi di sekolah. Hasil studi dokumentasi digunakan sebagai bukti bahwa peneliti sudah melaksanakan penelitian di lapangan observasi dan studi dokumentasi. Sedangkan Hasil dari penelitian ini yaitu: Program peningkatan mutu pendidikan di MAN 1 secara umum sesuai dengan delapan Standar Nasional Pendidikan (SNP). Program-program peningkatan mutu pendidikan telah dirumuskan meski masih bersifat global.
\end{abstract}

Kata Kunci: Excellent service, Implementasi,dan Madrasah 


\section{PENDAHULUAN}

Pelayanan publik di Negeri kita Indonesia ini masih sangat rendah. Seperti yang disampaikan oleh Bank Dunia dalam World Development Report (2002). Hasil penelitian Governance and Desentralization Survey (GDS) 2002 mendapatkan adanya tiga masalah yang sering terjadi di lapangan dalam pelaksanaan pelayanan publik, yang pertama, besarnya diskriminasi pelayanan.(Dwiyanto, 2003) Penyelenggaraan pelayanan masih terpengaruhi oleh adanya nepotisme, kesamaan afiliasi politik, etnis, dan agama.Hal tersebut masih sering terjadi meskipunsudah diberlakukannya UU No. 28 Tahun 1999 mengenai Penyelenggaraan Negara yang bebas dari KKN dan secara tegas memerintahkan adanya kesamaan pelayanan, bukannya diskriminasi.Kedua, tidak terdapat kepastian biaya serta waktu pelayanan. Ketidakpastian tersebut mengakibatkan timbulnya KKN, karena kebanyakan pengguna jasa condong memilih menyuap dengan dana tinggi pada penyelenggara pelayanan guna memperoleh kepastian seta kualitas pelayanan. Ketiga, rendahnya tingkat kepuasan masyarakat terhadap layanan publik.Ini menjadi akibatdari adanya diskriminasi pelayanan dan ketidakpastian.

Permasalahan mendasar pelayanan publik padahakikatnyamenyangkut peningkatan kualitas suatu pelayanan. Pelayanan dapat dikatakan berkualitas sangat tergantung pada beberapa aspek, yakni bagaimana pola pelaksanaannya atau tata laksana, dukungan sumber daya manusia, serta kelembagaan dan adanya konsep yang jelas. Dilihat dari pelaksanaannya, Pelayanan publik mempunyai berbagai kekurangan (Wahid, 2017) diantaranya :

1. Kurang responsif. Kondisi seperti ini hampir terjadi disemua tingkatan unsur pelayanan, mulai dari tingkatan petugas pelayanan (front line)hingga pada tingkatan penanggungjawab instansi. Tanggapan pada berbagai keluhan, pendapat, maupun harapan masyarakat sering terabaikan.

2. Kurang informatif. Berbagai informasi yang seharusnya tersampaikan pada masyarakat mengalami keterlambatan informasi bahkan terkadang tidak tersampaikan.

3. Jangkauan akses . Berbagai unit pelaksana pelayanan berada jauh dari jangkauan masyarakat, akibatnya membuat mereka kesulitan mendapatkan pelayanan tersebut.

4. Kurangnya koordinasi. Koordinasi yang kurang baik antara unit pelayanan satu dengan lainnya menyebabkan terjadinya kesenjangan atau perbedaan kebijakan 
antara instasi pelayanan satu dengan yang lainnya.

5. Birokratis. Pelayanan, khususnya pelayanan perijinan dilakukan berdasar beberapa proses dengan terdiri dari beberapa level, akibatnya penyelesaian pelayanan memakan waktu yang lama.

6. Kurang mendengarkan keluhan, saran, dan aspirasi masyarakat.Pada umumnya aparat pelayanan kurang peduli dalam mendengarkan keluhan, saran dan aspirasi dari masyarakat. Sehingga pelayanan yang diberikan tidak maksimal, cenderung apa adanya dan hal ini sering tidak berubah dari waktu ke waktu tanpa perbaikan.

7. Inefisien. Berbagai persyaratan yang diperlukan, khususnya dalam pelayanan perijinan sering tidak sesuai dengan apa yang diberikan. seringkali tidak relevan dengan pelayanan yang diberikan. Pelayanan dikatakan baik apabila dapat sesuai dengan standar pelayanan yang dipunyai lembaga pembei pelayanan tersebut.

Permasalahan mendasar pelayanan publik padahakikatnya menyangkut peningkatan kualitas suatu pelayanan. Pelayanan dapat dikatakan berkualitas sangat tergantung pada beberapa aspek, yakni bagaimana pola pelaksanaannya atau tata laksana, dukungan sumber daya manusia, serta kelembagaan dan adanya konsep yang jelas.Lembaga pendidikan (sekolah/madrasah) termasuk lembaga publik.Pelayanan yang menjadi produk dari lembaga pendidikan adalah pelayanan masyarakat (publik service). Pelayanan tersebut diberikan untuk memenuhi hak masyarakat, baik layanan sipil maupun publik.

Peningkatan standar mutu, Standar mutu yaitu standar yang ditentukanoleh lembaga penghasil produk untuk mutu produk yang dihasilkannya guna memenuhi kebutuhan konsumenpada kualitas produk yang dipakainya.Telaah mengenai standar mutu pada awalnya hanya dilakukan dalam dunia bisnis dan industri.Para pengusaha berusaha sebaik mungkin untukmenciptakan produk yang berkualitas agar bisa diterima dikalangan masyarakat.Seiring berkembangnya zaman telaah tandar mutu tidak hanya pada dunia bisnis melainkan sudah mengalami evolusi dalam berbagai bidang antara lainseperti manufactur, industri jasa, kesehatan, dan dewasa ini juga di bidang pendidikan. Saat ini minat dan ketertarikan pada standar tersebut benar - benar telahtersebar dalam pendidikan tinggi dan sekolah-sekolah.

Standar mutu pendidikan sekolah/madrasah dapat pula ditentukan oleh status akreditasi. Akreditasi yaitu suatu tolak ukur penentuan standar mutu dan penilaian 
terhadap suatu lembaga pendidikan salah satunya sekolah atau madrasah oleh pihak lain dari luar lembaga pendidikan itu sendiri. Dalam konteks Indonesia, lembaga yang berfungsi melaksanakan akreditasi sekolah/madrasah adalah BAN-SM

Peningkatan mutu berhubungan dengan target yang harus dicapai, proses untuk mencapai dan faktor-faktor yang berhubungan. Dalam hal initerdapat dua aspek yang perlu mendapat perhatian, yaitu aspek kualitas hasil dan aspek proses pencapaian hasil tersebut. Ada dua macam peningkatan mutu yaitu peningkatan mutu untuk mencapai standar mutu yang ditetapkan dan peningkatan mutu dalam hal peningkatan standar mutu yang sudah dicapai. Peningkatan standar ini dilakukan dengan kegiatan monitoring dan evaluasi (monev), evaluasi diri, audit, dan benchmarking.

Untuk melihat kekuatan atau kelemahan satuan pendidikan dalam hubungannya dengan upaya pemenuhan standar merupakan aplikasi dari evaluasi diri.Tahap berikutnya yaitu Audit Mutu Akademik Internal guna melihat kepatuhan pada standar mutu yang telah sudah ditentukan.Dalam upaya peningkatan mutu dilakukan melalui tahapan monitoring dan evaluasi, evaluasi diri, dan audit mutu internal serta ditambah dengan masukan dari seluruh stakeholders.Apabila hasil evaluasi diri dan audit tersebut menunjukkan bahwa standar mutu yang sudah ditetapkan belum tercapai, maka harus segera melakukan perbaikan agar dapat mencapai standar tersebut.

Akan tetapi jikahasil evaluasi diri serta an audit menyatakan bahwa standar mutu yang ditetapkan telah tercapai, maka pada proses perencanaan berikutnya standar mutu tersebut ditingkatkan melalui benchmarking.

Merurut Gregory H. Watson, benchmarkingmerupakan pencarian secara terus menerus dan penerapan secara nyata praktik-praktik yang lebih baik yang mengarah pada kinerja kompetitif unggul. Denagan kata lain sebagai Standar pembanding antara antar bagian dalam organisasi maupun dengan standar luar secara berkesinambungan dengan tujuan untuk peningkatan standar mutu.(Heller, 2001; Watson, 1993)

Terdapat tiga pertanyaan mendasar yang akan dijawab oleh proses benchmarking (Ruswidiono, 2011)yaitu:

1. Seberapa baik kondisi kita sekarang? (Evaluasi Diri),

2. Perlu menjadi seberapa baik? (Target),

3. Bagaimanakah supaya mendapatkan yang baik tersebut? (Rencana Tindakan).

Dalam konteks pendidikan di Indonesia, peningkatan kualitas pendidikan pada 
tingkat dasar dan menengah harus mengacu kepada Standar Pendidikan Nasional yang meliputi:

1. Standar kompetensi lulusan yaitutingkat kemampuan lulusan yang meliputi sikap, pengetahuan, serta keterampilan

2. Standar isi adalah ruang lingkup materi dan tingkat kompetensi yang dimasukkankedalam kategori kompetensi tamatan, kompetensi bahan kajian, kompetensi mata pelajaran, serta silabus pembelajaran yang mesti dicapai oleh peserta didik pada jenjang dan jenis pendidikan tertentu.

3. Standar proses, berhubungan dengan jalannya pembelajaran pada satu satuan pendidikan untuk mencapai standar kompetensi lulusan.

4. Standar pendidik dan tenaga kependidikan adalah kriteria pendidikan prajabatan dan kelayakan fisik maupun mental, serta pendidikan dalam jabatan.

5. Standar sarana dan prasarana, berhubungan dengan standar minimal mengenai ruang belajar, tempat berolahraga, tempat beribadah, perpustakaan, laboratorium, bengkel kerja, tempat bermain, tempat berkreasi dan berekreasi, serta sumber belajar lain, yang dibutuhkan guna menunjang proses pembelajaran, termasuk pemakaian teknologi informasi dan komunikasi.

6. Standar pengelolaan, berhubungandengan perencanaan, pelaksanaan, dan pengawasan kegiatan pendidikan pada jenjang satuan pendidikan, kabupaten/kota, provinsi, atau nasional agar tercapai efisiensi dan efektivitas penyelenggaraan pendidikan.

7. Standar pembiayaan, mengatur komponen dan besarnya biaya operasi satuan pendidikan yang berlaku selama satu tahun; dan

8. Standar penilaian pendidikan, berhubungan dengan mekanisme, prosedur, dan instrumen penilaian hasil belajar peserta didik.

Holsinger \& Cowell mengemukakan beberapa indikator mutu pendidikan, yaitu (1) pendidik, (2) peserta didik, (3) proses pembelajaran, (4) sarana dan fasilitas belajar, dan (5) manajemen sekolah. Indikator-indikator itulah yang menjadi penentu keberhasilan peningkatkan standar mutu di suatu sekolah.(Holsinger \& N. Cowell, 2000)

1. Pendidik

Keterlibatan pendidik secara maksimal dengan meningkatkan kompetensi dan 
profesi kerja pendidik dalam kegiatan seminar, Musyawarah Guru Mata Pelajaran, lokakarya danpenataran sehingga hasil dari kegiatan itu diterapkan disekolah.

2. Peserta Didik

Dalam hal ini dilakukan pendekatan anak sebagi pusat,agar kompetensi dan kemampuan peserta didik dapat digali sehingga sekolah dapat membina bakat peserta didik tersebut.

3. Proses Pembelajaran

Adanya kurikulum yang ajeg dan tetap tetapi dinamis serta suasana belajaryang nyaman, dapat memungkinkan dan memudahkan pencapaian standar mutu secara maksimal.

4. Sarana dan Fasilitas Belajar

Kelengkapan sarana dan fasilitas belajar ikut menentukan terciptanya kegiatan pembelajaran bermutu dan berkelanjutan

5. Manajemen Sekolah

Organisasi dan tata kelola sekolah mempunyai peranan penting dalam menjamin keberlangsungan standar mutu secara berkelanjutan dan berkesinambungan. Keberadaan kepala sekolah yang mempunyai dan mengerti visi kerja secara jelas, Tim Pengendali Mutu yang melaksanakan dan melakukan audit mutu secara berkala, serta dukungan stakeholder pendidikan akan menjamin proses dan hasil pencapaian standar mutu yang diharapkan.

Berdasarkan penelitian terdahulu, sudah ada penelitian yang meneliti mengenai excellent service dalam bidang pendidikan.(Rosy, 2017; Sanjaya, 2016; Widjajanti \& Sugiyanto, 2015a, 2015b). maupun penelitian mengenai peningkatan pelayanan (Lindawati \& Lubis, 2016; Noer, 2016; Purnama \& Sailah, 2017; Sari, Suwandi, Satria, \& Soeboer, 2017; Utami, 2017; Wibawa \& Purbokusumo, 2015; Widya, Agustiawan, Fibrian, \& Muttaqin, 2016) Namun belum adanya penelitian yang melakukan penerapan excellent service dalam sekolah MAN. Maka, penelitian ini bertujuan untuk menganilis kemampuan MAN 1 dalam menerapkan excellent service dalam bidang pendidikan

\section{METODE PENELITIAN}

Dalam penelitian ini digunakan pendekatan kualitatif. Menurut Kriek dan Miller 
dalam Moleong pendekatan kualitatif adalah pendekatan yang mengacu pada pengamatan manusia dalam bidangnya yang berkaitan dengan orang-orang tertentu mengenai bahasa dan peristilahannya yang merupakan tradisi tertentu dalam ilmu pengetahuan sosial.(Moleong, 2005)Penelitian ini menggunakan pendekatan kualitatif dengan metode deskriptif.Metode deskriptif digunakan karena sesuai dengan judul dan fokus penelitian yakni menggunakan fenomenologi. Menurut Moleong penelitian kualitatif merupakan penelitian yang bertujuan untuk memahami fenomena mengenai sesuatu yang dialami oleh subjek penelitian misalnya perilaku persepsi, motivasi, tindakan, dan lain-lain, secara holistik, sertamelalui cara deskripsi dalam bentuk katakata dan bahasa, pada suatu konteks khusus yang alamiah dan dengan memanfaatkan berbagai metode alamiah. (Moleong, 2005)Sugiyono menyatakan bahwa metode penelitian kualitatif amerupakan metode yang dipakai untuk meneliti dalam kondisi alamiah, dalam hal ini peneliti bertindak sebagai instrumen kunci, teknik pengumpulan data dkumpulkan secara triangulasi, analisis data bersifat induktif/kualitatif, serta hasil penelitiannya lebih menekankan pada makna.(Sugiyono, 2013)

Emzir mengemukakan bahwa pada penelitian fenomenologi, peneliti meneliti hakikat palaman manusia yang dipandang sebagai suatu fenomena, sebagaimana dipaparkan oleh partisipan dalam suatu studi.(Emzir, 2013)

Sedangkan Moleong menyatakan bahwa pendekatan fenomenologi adalah pandanganpemikiran melalui pendekatan pada pengalaman subjektif manusia. Dalam hal ini peneliti berusaha untuk memperoleh data dengan menyingkap peristiwa yang dialami oleh subjek penelitian, serta berusaha mengerti dan menginterpretasikan peristiwa tersebut.

Aktivitas analisis data menurut Miles dan Huberman yaitu data reduction, data display, dan conclusion drawing / verification.Reduksi data akan mempermudah peneliti dalam mengumpulkan data karena data yang direduksi menggambarkan secara jelas terhadap data yang sesuai dengan fokus penelitian. Data yang tidak sesuai dengan fokus penelitian akan dihilangkan agar tidak memperluas bahasan. Penyajian data dimaksudkan untuk memperoleh kecenderungan-kecenderungan atas fakta, serta memberikan kemungkinan adanya penarikan kesimpulan awal dan pengambilan tindakan lebih lanjut. Verifikasi data merupakan proses recheck selama masa penelitian dengan mencocokkan data dengan catatan-catatan yang telah dibuat peneliti ketika 
melakukan penarikan simpulan-simpulan awal. Data yang telah diverifikasi kemudian dijadikan landasan untuk menarik kesimpulan.

Uji keabsahan data dalam penelitiankualitatif diantaranya yaitu uji kredibilitas, transferabilitas, dependabilitas dan konfirmabilitas. Uji kredibilitas dalam penelitian ini menggunakan triangulasi, yaitu triangulasiteknikdan triangulasi sumber. Uji transferabilitasnya dengan uraian rinci.Melalui uraian rinci ini, terungkap berbagai hal yang dibutuhkan oleh pembaca sehingga dapat memahami temuan peneliti.

Konfirmabilitas yaitu standar yang digunakan untuk menilaimutu hasil penelitian dengan penelusuran dan pelacakan catatan/rekaman data lapangan dan koherensinya dalam interprestasi dan simpulan hasil penelitian. Untuk memenuhi pelacakan dan penelusuran, tersebut perlu menyiapkan hal - hal yang diperlukan seperti hasil rekaman, hasil analisis data, dan catatan tentang proses penelitian.

\section{HASIL PENELITIAN DAN PEMBAHASAN}

\section{Program Peningkatan Mutu Pendidikan}

Program pengembangan madrasah tercantum dalam rencana program jangka pendek, jangka menengah, jangka panjang, dan program unggulan.

Semua program tersebut dirancang dan disusun oleh suatu Tim Pengembang yang dipilih Kepala Madrasah dengan melibatkan berbagai komponen internal dan eksternal.Rancangan yang sudah disusun oleh Tim dimaksud lalu diajukan dalam forum rapat yang dihadiri oleh seluruh tenaga pendidikan, tenaga kependidikan, Komite Madrasah, dan stakeholder terkait lainnya. Rancangan program ini lalu disahkan oleh Kepala Madrasah yang diketahui oleh Ketua Komite Madrasah (wawancara dengan Kepala Madrasah tanggal 04 Oktober 2017)

Program pengembangan madrasah di MAN 1 bersifat bertahap dan mengacu kepada delapan standar pendidikan sebagaimana ditetapkan oleh Pemerintah.Rancangan program berkesinambungan yang dimulai sejak 2014 dengan rentang waktu sampai 2015 sebagai program jangka pendek.Sasaran program ini lebih banyak menekankan pada capaian peserta didik pada bidang akademik dan non akademik, seperti perolehan nilai Ujian Nasional, kelulusan peserta didik dan diterima di perguruan tinggi favorit, prestasi di ajang lomba penunjang akademik maupun non akademik.

Sementara rentang waktu program jangka menengah hingga tahun 2017.Sasaran 
program jangka menengah adalah meningkatkan capaian yang diraih pada program jangka pendek. Sasaran program jangka panjang menjangkau hingga tahun 2022 dengan target pencapaian maksimal dalam berbagai aspek.

Berdasarkan wawancara dengan Kepala madrasah, untuk mencapai sasaran yang telah ditetapkan, ada beberapa program peningkatan kualitas yang telah, sedang dan akan terus dilakukan. (Wawancara tanggal 04 Oktober 2017)

a. Peningkatan Kualitas dan Kapasitas Guru

Guru menempati posisi strategis dalam usaha peningkatankualitas pendidikan. Oleh karenanya, peningkatan kualitas serta kapasitas (kompetensi dan profesionalitas) guru mutlak perlu dilakukan agar mutu proses pembelajaran menjadi semakin lebih baik. Berkaitan dengan itu, beberapa kegiatan yang diselenggarakan adalah mendorong para guru untuk meningkatkan kualifikasi pendidikan ke strata dua (magister); mengikutsertakan dalam pelatihan, seminar dan workshop pendidikan; membina/membimbing dan mengevaluasi kegiatan pembelajaran melalui supervisi, meningkatkan kedisiplinan guru dalam melaksanakan tugas dan profesinya. Peningkatan kualitas guru dimaksud untuk memenuhi standar tenaga pendidikan, standar isi, standar proses, dan standar penilaian.

b. Peningkatan prestasi akademik dan non akademik peserta didik

Output peningkatan mutu akan tampak pada prestasi yang dicapai peserta didik, baik prestasi akademik maupun non akademik. Maka dari itu, bakat dan minat peserta didik dibina dan dikembangkan melalui ekstra kurikuler yang tersedia serta mengikutsertakan peserta didik dalam ajang perlombaan, baik pada skala lokal, regional, maupun nasional. Selain itu, pembinaan prestasi belajar dengan dilaksanakan melalui kegiatan belajar di asrama (bagi siswa yang diasramakan) dan tambahan jam belajar dalam bentuk bimbingan belajar (bimbel) di luar jam pelajaran.Peningkatan prestasi ini bertujuan untuk memenuhi standar kompetensi lulusan.

c. Peningkatan kinerja tenaga kependidikan

Tenaga kependidikan tidak dapat diabaikan perannya dalam menunjang proses pendidikan.Oleh sebab itu, kinerja mereka dalam memberikan pelayanan 
harus ditingkatkan.Pelatihan dan workshop sesuai bidangnya merupakan kegiatan yang diprogramkan, di samping pengawasan melekat secara internal.Program ini dikembangkan untuk mendukung tercapainya standar tenaga kependidikan.

d. Peningkatan sarana dan prasarana pendidikan

Gunamendukung proses belajar yang berkualitas, dukungan sarana dan prasarana mutlak diperlukan. Untuk itu, peningkatan kuantitas dan kualitas sarana dan prasarana pendidikan terus menerus dilakukan, seperti pengembangan asrama, laboratorium (komputer, fisika, biologi, dan kimia), penambahan jumlah koleksi buku perpustakaan, sarana olahraga, fasilitas ruang kelas belajar dan ruang kantor, serta sumber belajar berbasis internet. Program ini dilaksanakan untuk memenuhi standar sarana dan prasarana pendidikan.

e. Peningkatan kapasitas manajemen madrasah

Tata kelola madrasah menjadi bagian yang tidak bisadipisahkan dalam program peningkatan mutu pendidikan di madrasah. MAN 1 yang memiliki jumlah peserta didik yang relatif besar dan sumber daya yang relatif memadai harus dikelola dengan menerapkan tata kelola yang efektif. Semua pekerjaan terdistribusi habis ke seluruh bagian dan setiap personil pada masing-masing bagian memahami secara jelas pekerjaannya.Selain itu, untuk menjaga trust (kepercayaan) publik, baik dalam lingkup internal maupun eksternal, transparansi dan akuntabilitas pengelolaan sumber daya dan sumber dana menjadi prinsip utama yang diterapkan.

f. Peningkatan kemitraan dengan stakholder pendidikan

Keberadaan MAN 1 dengan capaian-capaiannya hingga saat ini, tidak terlepas dari dukungan para pemangku kepentingan (stakeholder). Meningkatkan kemitraan dengan stakeholder menjadi komitmen madrasah untuk menjamin dukungan terhadap program-program yang sedang dan akan dilaksanakan.

\section{SIMPULAN DAN SARAN}

Berdasarkan penyajian dan analisis data pada bagian sebelumnya, dapat disimpulkan: Program peningkatan mutu pendidikan di MAN 1 secara umum sesuai dengan delapan Standar Nasional Pendidikan (SNP). Program-program peningkatan mutu pendidikan telah dirumuskan meski masih bersifat global.

Saran yang dalam penelitian ini adalah program peningkatan mutu pendidikan di 
MAN 1 diharapkan dapat dirumuskan secara rinci dan spesifik dengan mengacu kepada EDM yang komprehensif dan berkesinambungan., Manajemen MAN 1 diharapkan dapat membuat program-program pengembangan kemampuan dan keterampilan pegawai secara terus menerus sehingga dapat meningkatkan pelayanan dan mutu madrasah. Kepala MAN 1 diharapkan untuk meningkatkan kualitas dalam implementasi pelayanan prima dengan lebih memperhatikan kebutuhan dan harapan masyarakat serta mutu sekolah, sehingga masyarakat merasa puas terhadap pelayanan yang diberikan oleh sekolah.Untuk mendapatkan informasi tentang kepuasan masyarakat secara akurat, survey opini pelanggan penting untuk dilakukan. 


\section{DAFTAR PUSTAKA}

Dwiyanto, A. (2003). Governance Practices and Regional Autonomy: Evidence from Governance and Desentralization Survey (GDS) 2002. Yogyakarta: Gadjah Mada University.

Emzir. (2013). Metodologi Penelitian Pendidikan Kuantitatif \& Kualitatif. Jakarta: Rajagrafindo Persada.

Heller, R. (2001). Riding the Revolution: How Businesses Can and Must Transform Themselves to Win the E-Wars. London: Profile Books Limited.

Holsinger, D. B., \& N. Cowell, R. (2000). Positioning Secondary School Education in Developing Countries. Paris: International Institute for Educational Planning/UNESCO.

Lindawati, \& Lubis, A. (2016). Peranan Kantor Perpustakaan, Arsip dan Dokumentasi dalam Peningkatan Pelayanan bagi Masyarakat. JPPUMA, 4(1), 42-58.

Moleong, L. (2005). Metode Penelitian Kualitatif. Bandung: PT Remaja Rosdakarya.

Noer, L. R. (2016). Analisis Peningkatan Kualitas Pelayanan Mahasiswa Magister Manajemen Teknologi ITS Surabaya Dengan Metode Servqual dan Importance Performance Analysis (IPA). Journal of Research and Technology, 2(1), 35-43.

Purnama, A., \& Sailah, I. (2017). Peningkatan Tingkat Kepuasan Dosen Terhadap Kualitas Pelayanan Pelatihan Jurnal Berkualitas Melalui Metode Servqual. Jurnal Manajemen, 21(3), 418-433.

Rosy, B. (2017). Sociodrama Method; Stimulate the Development of Attitudes , Knowledge and Skills of Students in Excellent Service Learning. Jurnal Pendidikan Bisnis Dan Manajemen, 3(1), 25-34.

Ruswidiono, R. W. (2011). Peningaktan Mutu dan Benchmarking Perguruan Tinggi. Jakarta: Media Bisnis.

Sanjaya, R. (2016). Multimedia Interaktif Pelatihan Service Excellent Menggunakan Pendekatan Story Based Learning. Jurnal Informatika, III(1), 100-106.

Sari, I. C., Suwandi, R., Satria, A., \& Soeboer, D. A. (2017). Peran Approaching Time Dalam Peningkatan Pelayanan Jasa Pemanduan Kapal di Pelabuhan Utama Tanjung Priok. Jurnal Teknologi Perikanan Dan Kelautan, 7(2), 191-198.

Sugiyono. (2013). Memahami Penelitian Kualitatif. Bandung: CV Alfabeta.

Utami, R. (2017). Implementasi Metode Importance Performance Matrix Untuk Evaluasi dan Peningkatan Pelayanan Perusahaan Jasa Care Cleaners. Kinetik, 2(3), 235-242.

Wahid, A. A. (2017). Reformasi Pelayanan Publik di Indonesia. Jurnal TAPIs, 14(1), 110. 
Watson, G. H. (1993). Strategic Benchmarking. New York: John Wiley and Sons.

Wibawa, S., \& Purbokusumo, Y. (2015). Peningkatan Kualitas Pelayanan Administrasi. $J K A P, 2(2), 38-51$.

Widjajanti, K., \& Sugiyanto, E. K. (2015a). Gaya Kepemimpinan dan Good Governance Sebagai Upaya Peningkatan Excellent Service Dan Kepercayaan Masyarakat (Studi Kasus Dinperindag Jawa Tengah). Jurnal Dinamika Sosbud, $17(2), 270-284$.

Widjajanti, K., \& Sugiyanto, E. K. (2015b). Good University Governance Untuk Meningkatkan Excellent Service Dan Kepercayaan Mahasiswa (Studi Kasus Fakultas Ekonomi Universitas Semarang). Jurnal Dinamika Sosbud, 17(2), 69-81.

Widya, M. A. A., Agustiawan, Y., Fibrian, I. D., \& Muttaqin, Z. (2016). Upaya peningkatan Pelayanan Administrasi Kependudukan Menggunakan Teknologi Informasi : Rancang Bangun Sistem Informasi di Desa Sumbermulyo Kecamatan Jogoroto Kabupaten Jombang. Register, 2(2), 51-59. 